\title{
The birth and potential death of IL28B genotyping for hepatitis $C$ therapy
}

\begin{abstract}
"Genotyping for IL28B broke onto the scene in 2009 with the discovery that a single nucleotide polymorphism in this gene was a predictor of sustained viral response in patients with dual therapy..."
\end{abstract}

Keywords: chronic hepatitis $\mathrm{C} \bullet$ interferon alfa $\bullet$ interleukin 28B $\bullet$ ribavirin $\bullet$ sofosbuvir

Worldwide, approximately 170 million people and approximately 3 million Americans are chronically infected with the hepatitis $\mathrm{C}$ virus (HCV) [1]. Persons with chronic $\mathrm{HCV}$ are at risk of liver disease progression, cirrhosis and hepatocellular carcinoma [2]. This RNA virus is transmitted through exposure of infected blood. Prior to the discovery of this virus in 1989, transfusion of blood containing the virus was the most common route of infection. Since the implementation of blood bank screening in 1992, intravenous drug use is considered the primary mode of transmission of $\mathrm{HCV}$ in the USA today [3]. Other risk factors include receipt of clotting factors before 1987, long-term hemodialysis, percutaneous or sexual exposure and HIV coinfection [3]. However, in approximately half of those infected with HCV, a risk factor is not identified and approximately three-quarters of all HCV infection occur in persons born from 1945 to 1965 [4]. Therefore, in 2012 in addition to risk factor screening, CDC added one time 1945-1965 birth cohort testing to its HCV screening recommendations [4]. Laboratory diagnosis of hepatitis $\mathrm{C}$ is performed through a combination of antibody screening using immunoassays, western blot confirmation and viral load testing using polymerase chain reaction. Genotyping of the infected virus is also an important criteria for therapeutic management [5]. There are six recognized genotypes with Type 1 being the most commonly encountered virus in the USA.

Prior to the development and release of direct acting antiviral (DAA) drugs, the treatment of choice for chronic hepatitis C infection was dual therapy with pegylated interferon alfa and ribavirin [6]. Patients with genotypes 1 and 4 were treated for 48 weeks while patients with genotypes 2 and 3 were treated for 24 weeks [3]. Overall about $50 \%$ of patients with hepatitis $\mathrm{C}$ infection treated with dual therapy achieved viral eradication with undetectable viral levels 6 months after completion of therapy termed sustained virologic response (SVR) [3]. Genotyping for IL28B broke onto the scene in 2009 with the discovery that a single nucleotide polymorphism in this gene was a predictor of sustained viral response in patients with dual therapy, in addition to spontaneous clearance of virus in the absence of therapy $[7,8]$. Patients with the CC genotype at location rs12979860 have a twofold higher incidence of SVR among hepatitis $C$ genotype 1 . The mechanism for this association is largely unknown. The frequency of the CC genotype is highest among Asian populations, intermediate among Caucasians and infrequent among African Americans [9]. Haplotype analysis with the addition of a SNP at rs8099917 provided further clarification of risk for individuals who were heterozygous (CT) at rs1297860 [10]. A third SNP has received some interest regarding hepatitis $\mathrm{C}$, as hemolytic anemia is a relatively common outcome with dual therapy, and can result in a reduction in dose duration among intolerant patients. SNPs found in the inosine triphosphatase gene that causes a deficiency in the production of this enzyme have been shown to be protective against

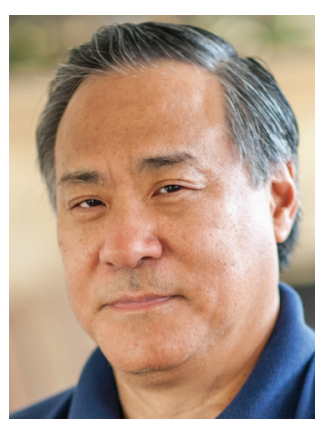

Alan HB Wu

Author for correspondence:

Department of Laboratory Medicine, University of California, San Francisco, CA 94143, USA

Tel.: +1 4152063540

Fax: +1 4152063045

wualan@labmed2.ucsf.edu

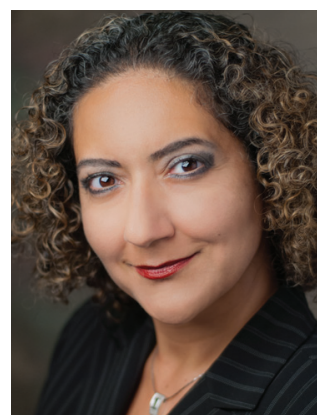

Mandana Khalili Department of Clinical Medicine, University of California, San Francisco, CA 94143, USA 
hemolytic anemia [11]. Pharmacogenomic testing for IL28B SNPs is available through reference laboratories and large academic institution.

\section{"...the development and approval of more potent direct acting antiviral therapy including interferon-free regimens for chronic hepatitis $\mathrm{C}$ has put into question the need and value of genotyping.}

In 2011, first-generation NS3/4A protease inhibitors boceprevir and telaprevir were approved for use in combination with interferon and ribarvirin in patients with genotype 1 to form 'triple therapy'; achieving higher rates of SVR in approximately $70 \%[12,13]$. Because boceprevir and telaprevir are more expensive than dual therapy, some have reported cost-effectiveness of use of dual therapy as first-line therapy for patients who carry the favorable CC genotype for IL28B in whom up to $80 \%$ reach SVR, reserving triple therapy for those in whom poor SVR is expected [14]. However, the development and approval of more potent direct acting antiviral therapy including interferon-free regimens for chronic hepatitis $\mathrm{C}$ has put into question the need and value of genotyping.

The most recent therapeutic advancement in hepatitis $\mathrm{C}$ drug therapy is release of the second-generation NS3/4A inhibitor, simeprevir for treatment for genotype 1 and the NS5B nucleotide polymerase inhibitor, sofosbuvir for all HCV genotypes (1 through 6) [15]. In Phase 3 clinical trials, triple therapy including sofosbuvir produced a $90 \%$ SVR at 12 weeks for hepatitis $\mathrm{C}$ genotypes 1 and 4 [16]. For patients with genotypes 2 and 3, the interferon-free regimen of sofosbuvir in combination with ribavirin for 12-24 weeks had similar SVR rates with a reduction in side effects [17]. These high rates of SVR were achieved even in those with unfavorable IL28B genotypes. This and other data have led the American Association for the Study of Liver Disease to recommend use of sofosbuvir combination therapy as first-line therapy for the initial treatment of patients with hepatitis $C$ [18]. For genotypes 1, 4, 5 and 6 , triple therapy with sofosbuvir, or dual therapy with ribavirin for those intolerant to

\section{References}

1 Armstrong LG, Wasley A, Simard EP et al. The prevalence of hepatitis C virus infection in the United States, 1999 through 2002. Ann. Intern. Med. 144(10), 705-714 (2006).

2 Perz JF, Armstrong GL, Farrington LA et al. The contributions of hepatitis $\mathrm{B}$ virus and hepatitis $\mathrm{C}$ virus infections to cirrhosis and primary liver cancer worldwide. J. Hepatol. 45 (4), 529-358 (2006).

3 Ghany MG, Strader DB, Thomas DL et al. Diagnosis, management, and treatment of hepatitis $\mathrm{C}$ : an update. Hepatology 49(4), 1335-1374 (2009). interferon was recommended. For genotypes 2 and 3, dual therapy with sofosbuvir and ribavirin is recommended. These recommendations are silent with regards to the role of IL28B genotyping in HCV therapy.

An important aspect of sofosbuvir-based triple treatment is the high cost that may limit access. This drug is more expensive than prior interferon-based regimens therapy with IL28B testing. Petta et al. performed a Markov modeling study and showed that sofosbuvir when added to dual therapy cost was below the willingness-to-pay threshold of 25,000 euro relative to first-generation protease inhibitors boceprevir and telaprevir-based triple therapy but not in those with favorable IL28B genotype [19]. However, currently in the USA, these first-generation protease inhibitors are no longer used in standard of care anti-HCV regimens [18]. Moreover, IL28B genotype do not seem to influence treatment response with use of anticipated additional newer potent direct acting and interferon-free anti-HCV therapies in the horizon [20-22].

It is premature to determine if the need for IL28B testing will diminish with implementation of potent DAAs- and interferon-free-based regimens. If the rate of SVR in clinical practice is as high as what is observed from clinical trials, there may not be a need for routine $I L 28 B$ genotyping prior to HCV therapy. However, high cost may prohibit access to these new agents especially in resource-limited countries, and alternative therapeutic approaches, as guided in part by IL28B pharmacogenomics may favor former approach of genotyping when using interferon-based therapies.

\section{Financial \& competing interests disclosure}

The authors have no relevant affiliations or financial involvement with any organization or entity with a financial interest in or financial conflict with the subject matter or materials discussed in the manuscript. This includes employment, consultancies, honoraria, stock ownership or options, expert testimony, grants or patents received or pending, or royalties.

No writing assistance was utilized in the production of this manuscript.

4 Smith BD, Morgan RL, Beckett GA et al. Recommendations for the identification of chronic hepatitis $\mathrm{C}$ virus infection among persons born during 1945-1965. MMWR Recomm. Rep. 61(RR04), 1-32 (2012).

5 Ghany MG, Liang TJ. Current and future therapies for hepatitis C virus infection. N. Engl. J. Med. 369(7), 679-680 (2013).

6 Manns MP, McHutchinson JG, Gordon SC et al. Peginteferon alfa- $2 \mathrm{~b}$ plus ribavirin compared with interferon alfa-2b plus rivavirin for initial treatment of chronic hepatitis C: a randomized trial. Lancet 358(9286), 958-965 (2001). 
7 Ge D, Fellay J, Thompson AJ et al. Genetic variation in $I L 28 B$ predicts hepatitis $\mathrm{C}$ treatment-induced viral clearance. Nature 461(17), 399-401 (2009).

8 Tanaka Y, Nishida N, Sugiyama M et al. Genome-wide association of IL28B with response to pegylated interferonalpha and rivavirin therapy for chronic hepatitis C. Nat. Genet. 41, 1105-1109 (2009).

9 Clark PJ, Thompson AJV, McHutchison JG. Genetic variation in IL28B: impact on drug development for chronic hepatitis C infection. Clin. Pharmacol. Therap. 88(5), 708-711 (2010).

10 Fischer J, Bohm S, Scholz M et al. Combined effects of different interleukin-28B gene variants on the outcome of dual combination therapy in chronic hepatitis $\mathrm{C}$ virus type 1 infection. Hepatology 55(6), 1700-1710 (2012).

11 Thompson AJ, Fellay J, Patel K et al. Variants in the ITA gene protect against ribavirin-induced hemolytic anemia and decrease the need for ribavirin dose reduction. Gastroenterology 139, 1181-1191 (2010).

12 Zeuzem S, Andreone P, Pol S et al. Telaprevir for retreatment of HCV infection. N. Engl. J. Med. 364(25), 2417-2427 (2011).

13 Poordad F, McCone J Jr., Bacon Br et al. Boceprevir for untreated chronic HCV genotype 1 infection. N. Engl. J. Med. 364(13), 1195-1206 (2011).

14 Liu S, Cipriano LE, Holodniy M et al. New protease inhibitors for the treatment of chronic hepatitis $\mathrm{C}$ : a cost-effectiveness analysis. Ann. Intern. Med. 156(4), 279-290 (2012).
15 Jacobson IM, Dore GJ, Foster GR et al. Simeprevir with pegylated interferon alfa 2 a plus ribavirin in treatment-naive patients with chronic hepatitis $\mathrm{C}$ virus genotype 1 infection (QUEST-1): a phase 3, randomised, double-blind, placebocontrolled trial. Lancet 384(9941), 403-413 (2014).

16 Lawitz E, Mangia A, Wyles D et al. Sofosbuvir for previously untreated chronic hepatitis C infection. N. Engl. J. Med. 368(20), 1878-1887 (2013).

17 Zuezum S, Dusheiko GM, Salupere R et al. Sofosbuvir and ribavirin in HCV genotypes 2 and 3. N. Engl. J. Med. 370(21), 1993-2001 (2014).

18 Recommendations for testing, managing, and treating hepatitis C. American association for the study of liver diseases. www.hcvguidelines.org

19 Petta S, Cabibbo G, Enea M et al. Cost-effective of sofosbuvir-based triple therapy for untreated patients with genotype 1 chronic hepatitis C. Hepatology 59, 1692-1705 (2014).

20 Ferenci P, Bernstein D, Lalezari J et al. ABT-450/rombitasvir and dasabuvir with or without ribavirin for HCV. N. Engl. J. Med. 370, 1893-1991 (2014).

21 Feld JJ, Lowdley KV, Coakley E et al. Treatment of HCV with ABT-450/r-ombitasvir and dasabuvir with ribavirin. N. Engl. J. Med. 370 (17), 1594-1603 (2014).

22 Afdhal N, Zeuzem S, Kwo P et al. Ledipasvir and sofosbuvir for untreated HCV genotype 1 infection. N. Engl. J. Med. 370 (20), 1889-1898 (2014). 